\title{
Hubungan antara Harga Diri, Kontrol Diri, dan Konformitas Remaja Terhadap Perilaku Seksual Pranikah
}

\author{
Indah Daratista*, Evi Kartika Chandra \\ Institut Agama Islam Ma'arif NU (IAIMNU) Metro Lampung, \\ Indonesia \\ @daratistaindah@gmail.com*
}

Submitted:
2020-04-11
Revised:
2020-05-12
Accepted:
2020-05-22
Copyright holder:
O Daratista, I. \& Chandra, E. K. (2020).
This article is under:
CC
How to cite:
Daratista, I. \& Chandra, E. K. (2020). Hubungan antara Harga Diri,
Kontrol Diri, dan Konformitas Remaja terhadap Perilaku Seksual
Pranikah. Bulletin of Counseling and Psychotherapy, 2(1).
Published by:
Kuras Institute
Journal website:
https://journal.kurasinstitute.com/index.php/bocp
E-ISSN:
2656-1050

\begin{abstract}
In Metro City, especially in the northern metro subdistrict, there are 5 high schools. Which consists of madrassas, private and public. Most of the students have already known the term dating (in a relationship with the opposite sex). Relationships established in adolescents, can trigger premarital sexual behavior. This study examines self-esteem, self-control, adolescent conformity and premarital sexual behavior. This research is interesting to discuss, because the results of this study are different from previous studies. Previous studies have a negative relationship between variables. But the results of this study indicate that the higher self-esteem, the higher the premarital sexual behavior. While the higher self-esteem of adolescents, the higher the self-control will be. When selfesteem and self-control go up, then adolescent conformity will also increase. The purpose of this study is to determine the relationships that arise between self-esteem, self-control, adolescent conformity and premarital sexual behavior. Which involved high school students in all sub-districts of the metro north of the city of metro, to be sampled in this study. The benefit of this research is to be able to increase the awareness of adolescents and the public about the dangers of premarital sexual behavior when performed. This study uses quantitative research with a correlation and survey approach. The results of this study are that there is a positive and significant relationship. Both the relationship between self-esteem with premarital sexual behavior, self-control with premarital sexual behavior, adolescent conformity with premarital sexual behavior, relationship between self-esteem with self-control, self-control with adolescent conformity, and self-esteem with adolescent conformity.
\end{abstract}

KEYWORDS: adolescents; conformity; premarital sexuality; self control; self-esteem

\section{LATAR BELAKANG}

Pada hakikatnya, setiap detik manusia pasti akan melakukan sebuah kegiatan. Kegiatan itulah yang disebut dengan perilaku. Remaja merupakan masa dimana mereka mengenal untuk menjalin hubungan dengan lawan jenis. Berawal dari menjalin hubungan, seorang remaja akan menimbulkan perilaku seksual yang dilakukan sebelum melewati masa pernikahan. Hal tersebut biasa dikenal dengan istilah perilaku seksual pranikah (Taufik 2013). 
Perilaku seksual pranikah merupakan masalah yang cukup berat, karena setiap tahunnya mengalami peningkatan. Dengan adanya dukungan biologis yang mendorong remaja untuk semata memperkuat hubungan, dan perkembangan teknologi yang semakin maju membuat remaja sangat mudah untuk mengakses informasi seksual. Faktor itulah yang membuat remaja merasa yakin untuk meniru (Rosalina, 2018). Menurut International Journal of Science Kesehatan Masyarakat (IJPHS) Vol.4, No.3, Remaja perilaku seksual pranikah merupakan salah satu permasalahan yang serius yang perlu ditangani oleh bangsa ini. Fenomena ini dalam masyarakat sering disebut dengan "cabecabean". Karena itulah perilaku seksual pranikah didefinisikan seperti berikut, yaitu semua bentuk tindakan menuju perbuatan seksual yang berasal dari hasrat seksual pada lawan jenis dengan remaja sebelum menikah, baik dari melakukan hubungan kurang intim untuk melakukan hubungan seksual seperti berciuman, berpelukan, petting, dan berhubungan layaknya suami istri (Suwarni, 2015).

Perilaku seksual pranikah merupakan persoalan yang dipengaruhi oleh berbagai faktor, baik dari dalam maupun luar diri remaja. Faktor dalam diri remaja yang mempengaruhi adalah harga diri. Harga diri merupakan suatu bentuk penilaian seseorang terhadap diri sendiri, baik dari segi positif maupun negatif yang dipengaruhi dari hasil interaksi dengan orang disekitarnya. Remaja yang memiliki tingkat harga dii yang rendah cenderung melakukan perilaku seksual pranikah (Rosidah, 2012).

Menurut Afiatin, Harga diri adalah suatu penilaian seseorang kepada dirinya sendiri, sebagai sikap penerimaan atau penolakan serta menunjukkan seberapa besar individu percaya pada dirinya, merasa mampu, berarti, berhasil dan berharga (Afiatin, 2004). Selain harga diri, terdapat faktor yang mempengaruhi perilaku seksual pranikah, yaitu kontrol diri dan konformitas.

Kontrol diri merupakan suatu kemampuan seseorang dalam membimbing, mengarahkan, dan mengatur perilakunya untuk menjadi seseorang yang lebih baik. Kontrol diri terbagi menjadi tiga jenis, yaitu kemampuan mengontrol perilaku, mengontrol kognitif, dan mengontrol keputusan (Wulaningsih, 2015). Remaja yang mudah dipengaruhi oleh teman sebaya, akan mengikuti apa yang dilakukan oleh tema-temannya agar dianggap sama (Indrayana, 2013). Perilaku seksual pranikah yang dilakukan oleh remaja membuat banyak pihak khawatir, baik pihak sekolah maupun keluarga. Oleh karena itu perlu adanya perhatian yang lebih dicurahkan pada permasalahan tersebut.

Di kecamatan metro utara kota metro terdapat 5 sekolah menengah atas, yang rata-rata siswanya cukup banyak. Siswa sekolah menengah atas merupakan remaja yang memasuki fase remaja tingkat madya dan akhir. Dari data prasurvey menunjukkan bahwa rata-rata siswa-siswinya sudah mengenal istilah pacaran atau menjalin hubungan dengan lawan jenis. Harga diri dan kontrol diri siswa cukup baik, namun sebagian siswa masih terpengaruh dengan teman sebaya. Ketika seorang remaja yang sudah menjalin hubungan dengan lawan jenisnya, maka ia akan melakukan halhal yang dapat memperkuat hubungannya.

Hal tersebut membuat peneliti merasa khawatir akan keadaan para remaja disekitar kecamatan metro utara, terkait tingkat harga diri, kontrol diri, konformitas dan perilaku seksual pranikah yang dilakukan oleh remaja. Dan mencari tahu apakah terhadapat hubungan antara perilaku seksual pranikah dengan harga diri, kontrol diri dan konformitas remaja. Tujuan yang hendak dicapai dalam penelitian ini adalah untuk mengetahui hubungan antara harga diri, kontrol diri, dan konformitas remaja dengan perilaku seksual pranikah di Sekolah Menengah Atas Se-Kecamatan Metro Utara Kota Metro.

\section{METODE}

Penelitian ini termasuk kedalam jenis penelitian kuantitatif, dengan memadukan metode penelitian korelasi dan survei. Penelitian ini mencari sebuah kebenaran terkait hubungan diantara variabel. Dan penyebaran kuesioner hanya dikumpulkan pada waktu tertentu untuk menggambarkan kondisi populasi (Bungin, 2018). Populasi pada penelitian ini adalah siswa/siswi kelas XI di Sekolah 
Menengah Atas se-Kecamatan Metro Utara, yang berusia sekitar 17-18 tahun. Dengan sampel yang digunakan sebanyak 240 responden, yang dihitung menggunakan rumus slovin.

Dalam penelitian ini, pengambilan sampel dilakukan kepada sesua siswa siswi yang menyetujui dan secara suka rela mengisi kuesioner yang diberikan peneliti (Arikunto, 2013). Metode yang digunakan untuk pengambilan sampel adalah stratified sample. Teknik pengumpulan data menggunakan teknik observasi, wawancara, kuesioner dan dokumentasi. Teknik analisis data yang digunakan adalah teknik analisis statistik dengan menggunakan software SPSS uji analisis korelasi (regresi sederhana).

\section{HASIL DAN PEMBAHASAN}

Berdasarkan hasil analisis data, dengan menggunakan aplikasi statistik SPSS (Statistical Package for Social Science) 16.0 untuk memperoleh nilai mean, standar deviasi, dan korelasi antar variabel. Data statistik harga diri, kontrol diri, konformitas remaja dan perilaku seksual pranikah dapat dilihat pada tabel 1.

Tabel 1. Hasil uji korelasi

\begin{tabular}{lcccc}
\hline Variabel & 1 & 2 & 3 & 4 \\
\hline 1 Prilaku seks pranikah & & & & \\
2 Harga diri & 0.196 & & & \\
3 Kontrol diri & 0.211 & 0.461 & & \\
4 Konformitas & 0.234 & 0.301 & & \\
Mean & 33.00 & 30.86 & 23.27 & 13.22 \\
SD & 3.556 & 4.675 & 3.007 & 2.157 \\
\hline
\end{tabular}

Dari data tersebut menunjukkan bahwa tingkat harga diri, kontrol diri, konformitas remaja dan perilaku seksual pranikah pada taraf sedang. Hasil analisis data selanjutnya, mengenai hubungan antara harga diri dengan perilaku seksual pranikah diperoleh korelasi sebesar 0.196 pada taraf signifikansi 1\%. Hal ini menunjukkan bahwa kedua variabel tersebut memiliki hubungan yang positif dan signifikan, meskipun kecil pengaruhnya. Hubungan positif kedua variabel tersebut menandakan bahwa semakin tinggi harga diri, maka kemungkinan akan semakin tinggi pula perilaku seksual pranikah yang dilakukan oleh para remaja.

Sedangkan hubungan antara kontrol diri dengan perilaku seksual pranikah diperoleh korelasi sebesar 0.234 pada taraf signifikan yang sama, yaitu $1 \%$. Hal ini menunjukkan bahwa kontrol diri dan perilaku seksual pranikah memiliki hubungan yang positif dan signifikan. Dari hubungan yang positif tersebut mendeskripsikan bahwa semakin tinggi kontrol diri maka kemungkinan akan semakin tinggi pula perilaku seksual pranikah yang remaja lakukan.

Sedangkan hubungan antara konformitas remaja dengan perilaku seksual pranikah, diperoleh korelasi 0.211 pada taraf signifikan 1\%. Hasil korelasi tersebut menunjukkan bahwa konformitas remaja dengan perilaku seksual pranikah memiliki hubungan yang positif dan signifikan. Hubungan antara harga diri dengan kontrol diri remaja menurut hasil pengolahan data diperoleh korelasi sebanyak 0.461 dengan taraf signifikan 1\%. Dari hasil penelitian tersebut, antara harga diri dan kontrol diri remaja memiliki hubungan yang positif dan signifikan. Hal tersebut menandakan bahwa semakin tinggi harga diri seorang remaja, maka akan semakin tinggi pula kontrol dirinya.

Terdapat hubungan yang positif dan signifikan pula pada hubungan antara harga diri dengan konformitas remaja. Karena nilai korelasi yang diperoleh dari pengolahan data penelitian ini sebesar 0.301 dengan taraf signifikan 1\%. Sedangkan hubungan antara kontrol diri dengan konformitas remaja, diperoleh nilai korelasi sebesar 0.237 dengan taraf signifikan 1\%. Hal tersebut menunjukkan bahwa kedua variabel tersebut memiliki hubungan yang positif dan signifikan. Dengan arti lain, bahwa semakin tinggi kontrol diri, maka akan semakin tinggi juga konformitas remaja yang dimiliki. 
Di era yang sekarang, para remaja bukan hanya mempertimbangkan harga diri mereka dalam suatu kegiatan yang baik saja, melainkan dalam keadaaan yang tidak bagus pun mereka akan mengutamakan harga dirinya. Ketika harga diri remaja tinggi, maka kontrol diri dan konformitas remaja juga akan terpengaruh. Dan jika harga diri remaja tersebut digunakan sebagai alasan dalam berperilaku seksual sebelum menikah, maka akan semakin tinggi pula tingkat remaja yang melakukan perbuatan seksual pranikah.

Mayoritas penelitian yang membahas mengenai harga diri dan perilaku seksual pranikah memperoleh hasil hubungan yang negatif. Penelitian yang serupa kebanyakan menjelaskan bahwa semakin tingginya harga diri maka akan semakin rendah perilaku seksual pranikah. Seperti hasil penelitian yang dilakukan oleh Anis Rosidah pada tahun 2012 mengenai "Religiusitas, Harga Diri dan Perilaku Seksual Pranikah Remaja". Juga pada penelitian Fridya Mayasari dan M. Noor Rochman Hadjan pada tahun 2016 yang membahas mengenai "perilaku seksual remaja dalam berpacaran dirinjau dari harga diri berdasarkan jenis kelamin". Namun pada penelitian kali ini berbeda, karena semua hasil hubungan yang ada semuanya adalah positif, dari satu variabel ke variabel lainnya.

Kelemahan dalam penelitian ini adalah cara mendapatkan data yang didapat hanya sekali. Selain itu, kuesioner yang dibagikan pada satu waktu dengan sistem pengisian kuesioner individual pada sampel. Sehingga keadaan sampel sangat mempengaruhi baik buruknya nilai hasil kuesioner, serta nilai reliabilitas dari salah satu variabel yang rendah. Oleh karena itu, peneliti berharap agar peneliti selanjutnya dapat melakukan penelitian longitudinal dengan variabel yang sama, namun dengan data yang di tes secara berulang-ulang.

Berdasarkan hasil kesimpulan yang diperoleh, maka dalam rangka meminimalisir terjadinya perilaku seksual pranikah yang terjadi pada kalangan remaja saat ini, peneliti memiliki saran kepada para remaja agar dapat memahami dan mengerti mengenai harga diri yang harus dipertahankan.

Bukan hanya mempertaruhkan harga diri untuk melakukan hal yang buruk, namun lebih baiknya jika mempertahankan harga diri pada kegiatan-kegiatan yang baik, yang tidak merugikan diri sendiri. Karna ketika harga diri seorang remaja digunakan dalam hal yang tidak baik, maka kontrol diri yang dimiliki akan terpengaruh kepada hal yang tidak baik juga.

Saran selanjutnya kepada para remaja, agar tidak terlalu mudah terpengaruh ajakan teman yang dalam hal ini merujuk pada perilaku seksual pranikah. Dikarenakan pada masa remaja, ajakanajakan yang digunakan sebagai pembuktian bahwa mereka sudah beranjak dewasa akan dilakukan tanpa berfikir panjang. Sedangkan akibat dari perilaku seksual pranikah sangatlah fatal jika terus menerus dilakukan.

Bagi peneliti selanjutnya, peneliti berharap agar penelitian yang selanjutnya dengan menggunakan variabel yang sama, namun dengan cara penelitian longitudinal dan pemberian kuesiner yang diberikan secara berulang-ulang.

\section{KESIMPULAN}

Berdasarkan analisa dan pembahasan yang dipaparkan oleh peneliti, maka dapat diambil kesimpulan bahwa semakin tinggi harga diri seorang remaja, maka kemungkinan akan semakin tinggi pula perilaku seksual pranikahnya. Semakin tinggi kontrol diri pada remaja maka kemungkinan akan semakin tinggi pula perilaku seksual pranikah. Semakin tinggi konformitas remaja, maka akan semakin tinggi pula perilaku seksual pranikahnya. Semakin tinggi harga diri remaja maka akan semakin tinggi pula kontrol diri yang dimiliki. Semakin tinggi harga diri yang dimiliki, maka konformitas remaja pun akan semakin tinggi. Semakin tinggi kontrol diri yang dimiliki, maka kemungkinan konformitas remaja akan semakin tinggi. Variabel harga diri, kontrol diri, konformitas remaja dengan perilaku seksual pranikah memiliki hubungan yang saling berkaitan. Jika salah satu variabel tersebut berhubungan dengan perilaku seksual pranikah, maka variabel lain juga akan mengikuti. 


\section{DAFTAR PUSTAKA}

Afiatin, T. (2004). Pengaruh program kelompok "AJI" dalam peningkatan harga diri, asertivitas, dan pengetahuan mengenai Napza untuk prevensi penyalahgunaan Napza pada remaja. Jurnal Psikologi, 31(1), 28-54.

Arikunto, S. (2013). Prosedur Penelitian Suatu Pendekatan Praktik, Jakarta: Rineka Cipta.

Bungin, B. (2005). Metodologi penelitian kuantitatif. Jakarta: Kencana.

Indrayana, P. (2013). Hubungan Antara Kecerdasan Emosional Dan Konformitas Kelompok Teman Sebaya Dengan Konsep Diri RemajaHubungan Antara Kecerdasan Emosional Dan Konformitas Kelompok Teman Sebaya Dengan Konsep Diri Remaja. Persona: Jurnal Psikologi Indonesia, 2(3).

Rosalina, A. F. (2015). Perilaku Seksual Pada Remaja Ditinjau Dari Religiusitas Dan Pola Asuh Permisif Pada Sma "X" Rowosari Kendal (Doctoral dissertation, Fakultas Psikologi UNISSULA).

Rosidah, A. (2012). Religiusitas, Harga Diri Dan Perilaku Seksual Pranikah Remaja. Jurnal Psikologi Tabularasa, 7(2).

Suwarni, L., Ismail, D., Prabandari, Y. S., \& Adiyanti, M. G. (2015). Perceived parental monitoring on adolescence premarital sexual behavior in Pontianak City, Indonesia. Int J Public Health Sci, 4(4), 211-219.

Taufik, A. (2013). Persepsi Remaja Terhadap Perilaku Seks Pranikah (Studi Kasus SMK Negeri 5 Samarinda). Ejournal sosiatri-sosiologi, 1(1), 31-44.

Wulaningsih, R., \& Hartini, N. (2015). Hubungan antara persepsi pola asuh orangtua dan kontrol diri remaja terhadap perilaku merokok di pondok pesantren. Jurnal Psikologi Klinis dan Kesehatan Mental, 4(2), 119-126. 